\title{
A History of Payment by Results: Lowe's Code (1862) and the Browne Report (2010)
}

\subsection{INTRODUCTION}

This chapter addresses the historical roots of present economic policymaking in higher education. A humanities critique is applied to the process of policymaking by close reading select committee reports, white papers, and Parliamentary debates. To date, a critical history of economic rationale in educational policymaking in England is poorly recorded. This chapter explores Payment by Results, a topic which has seldom been discussed at length within the context of education. ${ }^{1}$ I return to the foundation of the system of Payment by Results within educational policy reform in England during the 1860s as a tool to interrogate the present state of higher education. ${ }^{2}$ To this end, I will close read, contextualise, and analyse two seminal education policies: Lowe's Code (1862) and the Browne Report (2010). The chapter develops two distinct vignettes in order to demonstrate the prevalence and power of Payment by Results within the context of educational reform in England: one at the advent of debates in liberal education and the other within the current context of neoliberal

\footnotetext{
${ }^{1}$ William F. Connell observed that "a thorough history of the work of the Committee of Council on Education, and in particular, of the Payment by Results scheme, has yet to be written" $(1950,203)$ : a statement that is remains accurate until my attempt here.

${ }^{2}$ Although repetitive, "Payment by Results" is capitalised and used throughout this chapter in order to draw attention to the use of this term as a proper noun for this public policy instrument.
}

(C) The Author(s) 2020

Z. H. Bulaitis, Value and the Humanities, Palgrave Studies in Literature, Culture and Economics, https://doi.org/10.1007/978-3-030-37892-9_2 
education. Through these two distinct moments I trace the production, and re-production, of an economically motivated system in educational policy.

An interrelation of nineteenth and twenty-first century examples of economic incentives in teaching is useful for several reasons. First, as Regenia Gagnier argues in The Insatiability of Human Wants: "it is necessary to remind ourselves of the ways in which developments in economic thought were contested in the past because we find now that economism the tendency to interpret all phenomena in market terms - is widespread and influential" $(2000,5)$. In the aftermath of the Browne Report (2010) it can be difficult to imagine higher education outside a mindset of "economic growth" $(2010,14)$. However, the first application of the system of Payment by Results within educational policymaking throughout the 1860s was free from such limitations to alternative visions. In clarifying the historical context in which such an approach to policymaking was first developed, I suggest that Lowe's Code in the twenty-first century creates space and possibilities to respond with more critical nuance and historical awareness to the established form of the approach as currently experienced in higher education in England today. Second, I assert that this approach allows for a historical methodology and literary critique to be enacted on economic policymaking. This is a kind of re-humanising how scholars can talk about (or back to) white papers as potential narratives, about policymaking as historical contingency, and monocultures of economic value as a political agenda rather than an objective fact. This chapter highlights how a Payment by Results model of valuation has dominated government policymaking concerning the financing of higher education since 2008 . Broadly, Payment by Results is a performance-based system of pay that establishes minimum benchmarks of expectation and seeks to measure tangible outcomes in order to calculate success. A reliance on the assessment of minimum thresholds as opposed to maximums means Payment by Results is an approach that is readily adopted in times of austerity: limited criteria of value makes it cheap to administer. However, this approach had more profound effects than simply cost-cutting; as the system records only minimum levels of success, critics argue that the Payment by Results disregards more aspirational ambitions for education. Close analysis of policy processes and literatures represents the ways in which state processes reconfigure higher education as a private investment as opposed to a public good. Exposing the historical roots of policymaking approaches offers insight into current debates concerning value within the humanities and 
what action we might pursue in moving beyond such low expectations of higher education.

Sole reliance on the fiscal determinism of a Payment by Results system is an inappropriate register for the assessment of value in education. This chapter establishes a connection between a nineteenth and a twentyfirst-century policymaking example and their corresponding critique, in order to advance a critical consideration of educational values. The discussion is formed of two parts. The first section discusses the financial reform of elementary education under The Revised Code of Minutes and Regulations of the Committee of the Privy Council on Education in May 1862 (Lowe's Code henceforth). Debates in Parliament demonstrate a desire to control the cost of elementary education at a time when educational demand was rapidly expanding. ${ }^{3}$ Re-tracing the actions and articulations of educational values in Lowe's Code serves as a reminder that economism is a choice and not a natural or necessary part of the policymaking process. The second half of this chapter turns to the most recent iteration of Payment by Results within higher education: The Independent Review of Higher Education Funding and Student Finance (the Browne Report henceforth), 12 October 2010. The systemic changes that the Browne Report initiated, both in terms of government subsidy and the individual financing of higher education creates new tensions for the valuation of the humanities.

\subsection{PART I: LOWE'S CODE}

The Revised Code of Minutes and Regulation of the Committee on the Privy Council of Education, known as Lowe's Code, represents the first instance in which the British government adopted a system of Payment by Results approach on a national scale. Although the policy passed through the House of Commons in 1862, the process began in 1859 with the launch of the Newcastle Commission. The findings published as the "Report of the Commissioners appointed to inquire into the State of Popular Education in England" (Newcastle 1861) provided the evidence from which Robert Lowe, lst Viscount Sherbrooke, and his colleagues at the Privy Council of Education would construct Lowe's Code. Therefore, the investigations launched in 1859 represented the formation of the first

\footnotetext{
${ }^{3}$ Wardle, D. describes Lowe's Code "established value for money as the criterion for measuring the educational system, and [...] stood condemned under its own terms" $(1976,70)$.
} 
Payment by Results system in education in England and the start of "thirty-five years of experimentation with educational efficiency" (Rapple $1990,1)$. However, a history of policy starts with a debate and a committee, rather than a report. Therefore, in order to fully articulate the ways in which Payment by Results was first introduced into educational debates in England, the discussion in this section is organised chronologically. I characterise the important changes from Commissioners Report, through Parliamentary debates, finally turning to the establishment of Lowe's Code. The discussion concludes with an analysis of the critical responses of Matthew Arnold and Sir James Kay-Shuttleworth, who emphasised the shortcomings of educational assessment that established minimum expectations for financial reward.

\subsubsection{The Newcastle Commission}

In 1859, a Royal Commission was appointed under the chairmanship of the Duke of Newcastle "to inquire into the present State of Popular Education in England, and to consider and report what Measures, if any, are required for the Extension of sound and cheap elementary Instruction to all Classes of the People" (Newcastle 1861, 1). The Commission published its findings in 1861, proposing a new strategy that would radically alter the economy of education. Throughout the investigation into elementary education, the Newcastle Commission employed fifty-four inspectors, who collectively visited 9384 daily schools over the course of a year. The inspectors also visited 539 schools for pauper children, 118 Reformatory, Ragged or Industrial Schools and 38 training colleges. In total, the report claims that of the 10,075 schools inspected, 879,773 children were in attendance. Whilst these numbers demonstrate that under the attention of Kay-Shuttleworth educational quality and attendance had much improved throughout the mid-nineteenth century, the report nonetheless argued that "not more than one fourth of the children receive a good education" (Newcastle 1861, 295). ${ }^{4}$ After sitting for three years, the Committee published its recommendations in a six-volume report. The long and varied accounts of the fifty-four inspectors from regions across

\footnotetext{
${ }^{4}$ Kay-Shuttleworth served as the first Secretary of the Committee of the Privy Council of Education and established a national system of teacher training colleges during the 1840s.
} 
England offer a great deal of personal detail into the state of education in elementary schools.

However, given their scope and style, these findings were unwieldy and difficult to interpret as a whole. The report that the Newcastle Commission produced is indicative of the patchy assessment of schooling prior to 1862. Within the Commissioner's report, the methodologies of assessment varied tremendously: some inspectors provide personal accounts of conversations with members of the public, whilst others list the figures of literacy in each class, tabulated by age. Despite the quantity of information contained in the final report, the Duke of Newcastle and his team of inspectors were unable to provide a substantial framework for decisive action with which to remedy the situation they found. The most conclusive statement from the Commissioner's report states that "we have been obliged to come to the conclusion that the instruction given is commonly both too ambitious and too superficial in its character [...] and often omits to secure a thorough grounding in the simplest but most essential parts of instruction" (Newcastle 1861, 293). There was an "obligation" (293) to find a conclusion as opposed to a natural provision of one. The recognition that education was in need of reform is the only absolutely decisive conclusion of the six-volume report, whilst the means to achieving it is not addressed.

Despite its ambiguity, Robert Lowe used the finding of the Newcastle Commission to institute substantial educational reforms. In his chapter on "Culture and the Revised Code" in The Educational Thought and Influence of Matthew Arnold, William Connell observes that "the dependence of the Revised Code upon the report of the Newcastle Commissioners was made clear in the speech of Vice-President, Robert Lowe, in introducing the first revised version of the original Revised Code" $(1950,204)$. Lowe brought the first version of his code to the House of Commons on 13 February 1862. In this address, Lowe describes how the Newcastle Commission had revealed: "the evils of an inadequate quantum of teaching, a loose test of efficiency, far too expensive machinery, and a decline of the voluntary spirit" (HC Deb 13 February 1862 vol. 165 col. 214). On balance, the appraisal of elementary education that the Newcastle Commission offered was mixed and revealed a system that was complicated, unbalanced, and expensive. Lowe's attack on the "inadequate quantum of teaching" was misrepresentative, considering a large number 
of positive accounts of teaching within the report. ${ }^{5}$ However, Lowe's other criticisms are in accordance with the broad comments included in the extensive Newcastle Commission report.

Before turning to Lowe's reforms, one further passage of the Newcastle Commissioners Report is worth quoting at length. Although much of the report was site-specific and, therefore, difficult to extrapolate from, the following paragraph speaks to wider concerns. The Commissioners recommended the institution of

a searching examination by competent authority of every child in every school $[\ldots]$ to see that all the children under [the teacher's] charge really learned to read, write and cipher thoroughly well $[\ldots]$ and there can be little doubt that $[\ldots]$ if a teacher finds that his income depends on the condition that his scholars do learn to read, whilst another teacher is paid equally well whether they do so or not, the first will teach more children to read than the second $[\ldots]$ the object is to find some constant and stringent motive to induce them to do that part of their duty which is at once most unpleasant and most important. (Newcastle 1861, 157)

In this articulation of the apparent need for "a searching examination" (157), the argument for Payment by Results within education in England was born. The system of assessment is designed to provide the "result" of teaching their pupils to "read, write and cipher thoroughly well" (157). This is not an unreasonable minimum expectation of education especially given the lack of national organisation and ad hoc arrangement of schooling at the time. However, what is less clear-cut is the method of assessing this standard of education. Evidencing that one can read, write and solve mathematical problems is dependent on many factors. How can one be certain that a student is able to read, rather than recite from memory? How should one measure writing as being "thoroughly well" executed or not? What traits should this assessment include? Can the result of one test be indicative of the students' general aptitudes? These challenging questions cannot be fully answered with the simplicity of the method suggested above, and as critics were soon to observe, it denoted a lack of consideration for such qualitative difficulties.

\footnotetext{
${ }^{5}$ For example, see Newcastle (1861) commentary on reformatory schools (413), the Royal Carriage schools at Woolwich (422) and parish free schools in Lincoln, Gainsborough \&c. (463) are all explicitly described as being "excellent" in the Commissioners report.
} 
The Commission proposed the endorsement of a Payment by Results approach because of the poor level of teaching of "the Three R's" (reading, writing, and arithmetic). ${ }^{6}$ This deficiency posed a large problem for elementary schooling, as these rudimentary skills are the foundations of more advanced studies. What is perhaps most surprising to a contemporary reader is the assertion that the reason for the deficiency is that these skills were the "most unpleasant" (Newcastle 1861, 157) duty that teachers were required to undertake. The report argues that if a teacher is not paid directly to teach the Three R's, then they are "bound" (157) to neglect them. Such assertions were not unusual at the time; prior to the commission's findings in 1861, evidence of sporadic teaching is frequently found in the annual reports of school inspectors. Reverend J. P. Norris offers a particularly prominent example in his General Report for the Year 1858 in the Counties of Chester, Salop and Stafford. Norris makes specific reference to how "the task of geography and history is far easier and less irksome than that of teaching to read and write" and urges that "teachers should give their principal attention to these essential subjects" (qtd. in Newcastle 1861, 248). Therefore, Payment by Results was partially invented to ensure that teachers were fulfilling a minimum expectation of educative responsibility. The Newcastle Commissioner's report insisted that "the object [of policymakers] is to find some constant and stringent motive to induce [teachers] to do that part of their duty" (157). This foundational desire to create a uniform and democratic, albeit limited, system of elementary education is predicated upon the belief that access to basic schooling was a national imperative and responsibility. The Commissioners report records how,

three-fourths after leaving school forget everything they have learnt there; and we are desirous to suggest inducements by which the schoolmaster, while still chiefly interested in completing his work with his elder scholars, shall find it worth his while to give that sound foundation to the younger boys, which shall enable them, if so minded, afterwards to complete their education for themselves. (Newcastle 1861, 321)

The Newcastle Commission found that students had forgotten how to read and write after leaving education; therefore, it is not only the content

\footnotetext{
${ }^{6}$ The Three Rs are rumoured to have been coined by William Curtis, who is described in the most unflattering manner as "a portly and bottlenosed bon vivant and unconscious buffoon" in Thorne, R. (1986). It is claimed that during an after-dinner speech for the Board of Education around 1795, Curtis humorously slurred the words "reading, 'riting, and 'rithmetic" (qtd. in Timbs 1825, 75).
} 
of an education that was forgotten but also the means to pursuing further learning. The desperate need to be able to assess a level of competency in a complicated system is evident in the Newcastle Commission's recommendation of the Payment by Results approach. The government sought to bring order to a fragmented and uneven system and the inspectors identified the 3 R's as a primary means by which to begin this national educational reform.

Such democratising aspirations were not inherently economic and the desire for greater organisation and better teaching quality should not be condemned as unnecessary in the context of the fragmented and expanding school system in the mid-nineteenth century. However, Lowe's decision to pursue a policy that was built on an extremely limited model of assessment demonstrates that his principal desire was for reform to aid economic control and administrative efficiency. Undeterred by the indiscriminate findings of the Newcastle Commission, Lowe keenly assumed the task of reforming the structures of elementary education in England as he saw fit. The following section explores Lowe's particular influences and the consequences of economic motivations shaping educational policymaking.

\subsubsection{Robert Lowe and Economic Motivations}

Although the need for greater organisation is explicitly presented in the Newcastle Commissioner's report, the investigation into elementary schooling was motivated by a different, although somewhat contingent, demand. By 1860, the government was in desperate need of financial retrenchment and the requirement for economic scrupulousness resided within the original request of the Newcastle Commission. The task appointed to the Duke of Newcastle was to recommend potential improvements for "the extension of sound and cheap elementary instruction" (Newcastle 1861, 4). For Lowe, and others in the Committee on the Privy Council of Education, "sound and cheap" (4 my italics) fulfilled the requirement of "a minimum standard of education" (Hansard "Mr Lowe" 1862a, vol. $165 \mathrm{col} .214$ ). The use of "sound" in the request of the Newcastle Commission is indicative of the governmental interest in attaining a level of sufficiency rather than an interest in high-quality education. Furthermore, the direct implication of "cheap" demonstrates that any suggestions or improvements needed to be relational to reductions in cost. An economic interest plays an important part in the changes to 
education that were implemented by Lowe's Code. Throughout the period of debate and revision in Parliament, Lowe persistently asserted the benefits of Payments by Results as the preferred system of assessment. In order to implement order into education at elementary level, Lowe argued that "a minimum of education" (Hansard "Mr Lowe" 1862a, vol. 165 col. 237) was the most important factor to assess.

At this juncture, it is significant to note that Lowe is not remembered as a great reformer of education, but rather for his position as Chancellor of the Exchequer (1868-73) under William Gladstone as Prime Minister. Lowe's legacy is his rationalist approach to policymaking; Connell observes how he "abhorred administrative untidiness and longed to see [his] work based logically with Benthamite purity and simplicity, upon a few clear principles" $(1950,208)$. Lowe's intention in 1861 was to both organise and economise the system of elementary education.

Under Payment by Results, financial rewards are provided for successful performance within specific criteria of assessment: above all else, a focus on basic utility saturates this approach. Lowe was greatly inspired by the economic theory of Adam Smith and believed that "education is no exception to the rules of Political Economy" (Lowe 1868c), frequently referencing Smith's thinking in discussions of educational reform. ${ }^{7}$ Lowe's inclusion of education as a field that is suitable for economisation is unsurprising given his belief in the universal applicability of Smith's economic principles. In "Private Versus Public Education: A Classical Economic Dispute" Edwin West documents how "Lowe felt that Smith's presumption that competition was necessary to overcome the natural desire of every man to live as much at his ease as he could, was sincerely intended as a universal principle" $(1964,472)$. Lowe's Smithian perspective saw education as the responsibility of the parent and not the state, and the rise of competition within school assessment as being a means with which to induce teachers (prone to the pursuit of an easy life) to offer a sufficient level of education at the lowest price. Therefore, Payment by Results was instituted in England during the 1860s as an economically motivated ideology that aspired towards a utilitarian efficiency. Huriya Jabbar argues that "Lowe's emphasis on technical efficiency, and his reliance on incentives rather than mandates to induce teachers to improve student achievement, suggest[s] an approach to policy that arose out of his particular applications of economics to education rather than the general

\footnotetext{
${ }^{7}$ See Lowe, R. (1868c).
} 
climate" $(2013,228)$. As a proponent of liberal free trade who primarily understood policy from an economic perspective, Lowe believed that education should be understood as a commodity, and like any other, could be managed through the application of an efficient political economy.

The belief that all aspects of society can be managed as a free market is, to humanities scholars and educators alike, a categorical error. Lowe's disregard for the idea that teaching ability might be motivated by anything other than financial incentive is particularly extreme. Helen Small identifies how Lowe's personal experience of complacent educators during his education at Winchester College likely "intensified his contempt for the low general standard of university education" $(2013,71)$. Lowe wrote how "no occupation [is] more likely to degenerate into lifeless routine and meaningless repetition" $(1868 \mathrm{c}, 8)$ than teaching. There is no evidence that Lowe understood that an individual's experience of education, as a student or as a teacher, could be potentially transformative or inspirational. Although, of course, Lowe is not the sole reason that Payment by Results was adopted in England in 1862, his personal experiences and perspective on economic theory should be acknowledged, given his vital role in the policymaking process.

National spending on elementary education had been steadily increasing throughout the 1850s. This was largely owing to the excessive administrative processes that were insufficiently organised to deal with a large number of personal enquiries over salary and grant payment in schools. The Newcastle Commission identified the "complication of the business" $(1861,328)$ of education as being in need of major redress. By 1859 the annual government expense in education grants was in excess of $£ 723,000$. Compared to national expenditure at the time, this was a relatively small cost: in the same year the price of the Crimean War (1853-56) was approaching $£ 78,000,000 .{ }^{8}$ The high financial cost of the war played a significant role in the need for cutbacks in public spending during Gladstone's government throughout the 1860s. "Gladstone took over a $£ 5$ million deficit" (Jenkins 2012, 215) as Chancellor of the Exchequer in 1859 and, therefore, the need for reducing government spending was imperative. Connell suggests that "the real genesis of the Revised Code [Lowe's Code] lay in the current demand for the retrenchment [of] the inflated income tax that had been built up during the Crimean War"

\footnotetext{
${ }^{8}$ The Advocate of Peace documents "crushing taxes, an augmented national debt, and expensive floating liabilities"(1869, 117).
} 
(1950, 206). Brendan Rapple concurs: "the run on the coffers due to the Crimean War" meant that in educational policy at the time it "was a sine qua non that it would be cheap" $(1990,3)$. Such accusations of purely fiscal intent ignore the moral interests that were present in the Newcastle Commissioner's report. The focus on financial savings did not appear to motivate the initial commission, which stated that, in terms of state grants to education, "it would not be desirable either to withdraw it or largely diminish its amount" (Newcastle 1861, 297).

Further evidence of the increasing interest in the economisation of education is found in a speech that Granville George Leveson-Gower (the Second Earl Granville) made in the House of Lords, 13 February 1862. He describes the state grants offered to schools under the initial proposal as follows: "one third [...] of the sum thus claimable is forfeited if the scholar fails to satisfy the inspector in reading, one-third, if in writing, and one-third in arithmetic" and emphasises that "if they fail in all, the State will contribute nothing towards the maintenance of the school" (Hansard "Earl Granville" 1862b, vol. 165 col. 173). The proposed system of assessment of elementary education was divided into three equal parts; the limited tests would be relatively easy to administer and would lead to a greater consistency in inspectors' reports. Here, an observable leap has been made from the recommendations of the Newcastle Commission to the creation of Lowe's Code. Whilst in its initial imagination of Payment by Results, the Commission was keen to find "some constant and stringent motive to induce" (Newcastle 1861, 157) teachers to engage students in essential studies, it seems that their metaphor of payment was taken quite literally by policymakers. By 1861, grants were to be administered "on sufficiently stringent conditions" (Hansard "Mr Lowe" 1861, vol. 164 col. 734) and thus an idea initially conceived to motivate teachers became mandatory. Performance related pay is identified as an example in the Newcastle Report, but not an endorsement or a clear proposition. Regardless of the original intention of the Commission, the "constant and stringent motive" (Newcastle 1861, 157) was henceforth integrated into law as a monetary reward.

The proliferation of the language of economic utility is frequently found in discussions of the revisions to educational policy at the time. Granville exhibits an exemplary economic register in his speech to the House of Lords. For instance, he rejoices how "the result $[\ldots]$ will be contemporaneous with enormously increased efficiency in the schools, and with a great increase in the amount of useful instruction received by 
the children" (Hansard "Earl Granville" 1862b, vol. 165 col. 174). Once more the "amount" of educational knowledge being transmitted is the principal concern, as opposed to the quality. The language that Granville uses to discuss schooling is wholly economic: "increase", "efficiency", "amount", and "useful[ness]" are its primary objectives. It is unsurprising that, in a time of financial retrenchment, Lowe's economically driven project was popular in government. Those with sensitivities towards efficiency welcomed the suggestion that the chaotic system of assessment in elementary education might be curbed into three easily defined areas of knowledge.

Affirmation of this economised view of the Payments by Results method is explicated in a letter written in 1882 from Lowe to Ralph Lingen (then Permanent Secretary of the Education Department 1849-70). Reflecting upon the last twenty years under which the system of Payment by Results had dominated the assessment of elementary education, Lowe describes the economic perspective of his approach in some detail. The letter admits how he chose a system that "was more a financial than a literary preference" $(1893,217)$. This, Lowe continues, enabled "useful knowledge" with "precision" to be administered in elementary schools. This definition typifies Lowe's view of the structures of elementary education requiring efficiency. For Lowe, "the Three R's" were the most useful knowledge available in elementary education. This is not, as the Newcastle Commission identified, because these subjects were the foundational blocks in the educative process, but rather because they conveniently provided "an amount of knowledge which could be ascertained thoroughly by examination" (Lowe 1893, 217). Use, for Lowe, was not a foundational starting point or an element in a complicated world of compounds: use was the result. Under Lowe's Code, any "amount" of knowledge that could not be accurately and "thoroughly" assessed was useless to the government's grants body.

Under Lowe's Code educational grants to schools were "on average reduced [by] two-fifths" (Shuttleworth 1861, 4). In "The Cult of Efficiency in Education: Comparative Reflections on the Reality and the Rhetoric" Anthony Welch charts how "the scheme had a profoundly depressing effect upon both monies expended by the state upon elementary education (the grant fell from $£ 813,441$ in 1861 to $£ 636,806$ in 1865 ) and also heralded a precipitous decline in numbers of pupil teachers and teachers' college trainees" $(1998,165)$. Lowe's Code directly reduced the costs associated with financing education and indirectly demotivated a 
generation of prospective educators. In his 1867 general report on Elementary Schools, Matthew Arnold described how "in 1861, [there was] one pupil-teacher for every thirty-six scholars; in 1866 it was one pupil teacher for every fifty-four scholars" (1889, 111). Arnold argues that this drop in student-teacher ratio was accompanied by a decline in the quality of education provided. His report directly attributes the change to Lowe's Code lamenting that

the mode of teaching in the primary schools has certainly fallen off in intelligence, spirit, and inventiveness during the four or five years which have elapsed since my last report $[\ldots]$ In a country where everyone is prone to rely too much on mechanical processes, and too little on intelligence, a change in the Education Department's regulations, which by making twothirds of the Government grant depend upon a mechanical examination, inevitably gives a mechanical turn to school teaching, a mechanical turn to the inspection, is and must be trying to the intellectual life of a school. $(1889,121)$

Marcham observes how Payment by Results is "normally regarded by educationists as retrogressive and by administrators as advantageous" (1979, 132). The system implemented in 1862 made the system of governance efficient and cheap, as it simultaneously reduced the qualities of an education to a mechanical process with a culture of minimum values. Arnold observed a correlation between the reform of value assessment in education, in the adoption of Payment by Results, and the "mechanical turn to school teaching" $(1889,121)$. Further analysis of the critical response from Arnold to the reallocation of teaching grants, alongside the interventions of James Kay-Shuttleworth, are addressed in the following section.

\subsubsection{Critical Responses to Payment by Results}

Such an economised system has obvious neglects; with the gain of efficiency of administration and assessment came the loss of creative practice and concern for quality. As a consequence, there was significant public and political debate surrounding the educational reforms during 1861-62. Shuttleworth and Arnold were among the loudest campaigners against Lowe's Code. Arnold's “The Twice-Revised Code", published in Fraser's Magazine, March 1862, was written in support of Shuttleworth's "Letter to Earl Granville, K.C., on The Revised Code", July 1861. Although 
Shuttleworth's letter was arguably "the most powerful and important pamphlet that appeared early in the controversy" (Connell 1950, 211), it was written in technical language, was over 80 pages long, and was primarily designed to address politicians who were already aware of the debate. As Arnold states in his introduction to the "Twice-Revised Code", although Shuttleworth's attack on the adoption of Payment by Results is well founded, it is "too copious" $(1862,212)$ for a general reader. Arnold realised that his strength as a cultural communicator would make the subject more widely accessible. In a letter to his mother, dated 26 February 1862, Arnold describes how he had set about "presenting the subject in its essence, free from those details with which it is generally encumbered, and which make 'outsiders' so afraid of it" (Letters of Matthew Arnold 1895, 185 italics original). The "Twice-Revised Code" is an elegantly argued and entertaining extrapolation of educational theory and debate. Arnold clearly identifies Lowe as a "political economist" $(1862,243)$ as opposed to an educational reformer. He argues that Lowe's Code was legislation intended to organise, economise, and constrain elementary education into a mechanical system. However, rather than setting a minimum standard for quantified learning, Arnold aspired towards a "general intellectual cultivation" (1862, 224 italics original) for all children in England. This, he argued was a "debt and a duty on the State's part" (240 italics original).

Arnold identified three main problems with Lowe's Code in "The TwiceRevised Code". First, he argued that the method of assessment proposed fostered automatism instead of intelligence; second, that the system was damaging to the teaching profession; and third, that the policy was informed by an interest in economics as opposed to qualities of a liberal education. In broader terms, these three grievances stand in opposition to the establishment of a culture of minimum rather than maximum valuation of education. Payments by Results, under the government of 1862, sought to establish an efficient but rudimentary test for elementary education and little more. The proposed system demanded a small and precise amount of knowledge to be assessed. This set of specific criteria limited the role of the school inspector to carrying out a mechanical process. In a particularly animated hyperbole, Arnold aligns the classroom with a battalion in an army, and school inspectors to the rank of generals. Lowe's Code, he allegorises, "is as if the generals of an army $[\ldots]$ were to have 
their duties limited to inspecting men's cartouch-boxes" (1862, 235). ${ }^{9}$ The limited and minimal assessment criteria are seen to neglect many of the other important factors of education institutions. He continues: "the camp is ill-drained, the men are ill-hutted, there is danger of fever and sickness. Never mind; inspect the cartouch-boxes! But the whole discipline is out of order, and needs instant reformation: - no matter; inspect the cartouch-boxes!" $(1862,235)$. For Arnold, measuring minimum standards in limited subject areas jeopardises the wider project of education. The metaphor of the army is an effective image, with the inference that, like the military forces, schools are responsible for the defence of national interests. It is also perhaps a shaded criticism of the amount of money spent in the Crimean War in comparison to the relatively small cost of education. Choosing to assess only a limited and precisely specified amount of knowledge was a dangerous approach in Arnold's opinion; he argued that teachers would not be motivated to educate pupils to their highest potential but rather instead to conform to the expected regulations of government assessment. Small describes how, for Arnold, "an education is of value in its deepest civilizing and life-long effects, not primarily for its turning out of functional literates" $(2013,74)$. Arnold argued that under the revisions of Lowe's Code "the Teacher [...] is led to think, not about teaching his subject, but about managing to hit those requirements" (qtd. in Connell 1950, 225). The tension between Lowe and Arnold was because of an entirely dissimilar belief and approach to the valuation of education.

The impact of Arnold's “Twice-Revised Code" is difficult to measure. As with the creation and revision of any government policy, a large number of agents and agendas shaped the effects and implications. However, before Lowe's Code was finalised in the summer of 1862, a copy of the "Twice-Revised Code", thinly veiled in anonymity, was sent to every member of both of the Houses of Parliament. One significant amendment in the February 1862 session of Parliament was that "[a] third of the grant instead of none at all, was to depend solely upon a pupil's attendance" (Connell 1950, 217). Therefore, the limited criterion for payment was widened to include attendance, a small concession towards engaging students as individuals through recognition of their participation in education. Arnold and Shuttleworth could not stop the implementation of

\footnotetext{
${ }^{9} \mathrm{~A}$ cartouch-box is a pouch as part of the military uniform that was purely ornamental of Britain from 1840 onwards.
} 
Payment by Results across all elementary education in England, and Arnold would continue to protest against the system for over thirty years until his death in 1888. In his school inspection report in 1867, Arnold describes "a deadness, a slackness, and a discouragement which are not the signs and accomplishments of progress [...] certainly to be attributed to the school legislation of $1862 "(1889,110)$. It is tragic, or perhaps a fitting memorial, that in the year of Arnold's death the tide turned against the system of Payment by Results in elementary education in England.

Throughout the late 1800s, the system adopted under Lowe's Code was continually revised and eventually dismissed entirely. In 1888, the Cross Commission reported that "we are unanimously of the opinion that the system of 'payment by results' is carried too far and too rigidly applied, and that it ought to be modified and relaxed in the interests equally of the scholars, of the teachers, and of education itself" (Cross Commission $1888,183)$. From the stringent economic base of Lowe's Code, the policymakers reformed and revised the system of elementary education. ${ }^{10}$ The acknowledgement of the need for a more "relaxed" approach to teaching went some way to heal the damaged relationship between public inspectors and educators. However, as Howard Barnard observes "a feeling of hostility [...] outlived the system of "payment by results" (1958, 131). Shuttleworth commented retrospectively in his Memorandum on Popular Education that "the Revised Code has constructed nothing; it has only pulled down" $(1868,30)$, a feeling that Arnold shared. From the outset, Lowe confessed limitations of his revision in an address to the House of Commons: "I cannot promise the House that this system will be an economical one, and I cannot promise that it will be an efficient one, but I can promise that it shall be either one or the other. If it is not cheap it shall be efficient; if it is not efficient it shall be cheap" (Hansard "Mr Lowe" 1862a, vol. 165 col. 229). The two main concerns Lowe observed in the structures of elementary education were inefficiency and economic cost.

These were undoubtedly faults in the education system that Lowe's Code addressed. Lowe's view of the landscape of elementary education was always from an administrative and economic perspective and in this regard he was successful. Arnold and Shuttleworth's admonishment is rooted in the neglect of the qualitative and ambiguous systems inherent within the processes of education. In "Mr Walter and Schoolmasters'

\footnotetext{
${ }^{10}$ See Forster's Act (1870) and The New Code (1890) which reverses Lowe's Code's legislation.
} 
Certificates", an article published anonymously in the London Review, 11 April 1863, Arnold argued that "Mr Lowe was never weary of disparaging all securities except this one security of results; he could not sufficiently scout the motion of paying for the 'means' instead of solely paying for 'results" $(1863,259) .{ }^{11}$ Arnold's accusation is that only things that are visibly available for measurement are elected as the benchmark for success. This valid observation present throughout "Twice-Revised Code" identifies the principle difficulty facing the security of the "free creative activity [...] the highest function of man" (Function of Criticism 1864, 28) of liberal education. In the pursuit of knowledge (and by relation, for Arnold, contentment) the Payment by Results system of the 1860s flattened education to a system of minimal expectations and financial motive.

The use of Payment by Results in education slowly diminished at the end of the nineteenth century, and by 1897 had been fully removed. The focus on the "Three Rs' had diminished and more subjects were included in school curricula, the assessment of all individual students was relaxed to a broader inspection of the school. Alongside the Cross Commission, above, the "Code of Regulations for Day Schools" in 1895 was a turning point in the minimal assessment of education. For example, in infant schools, the 1895 code instituted "a variable grant of 2 s., 4 s., or $6 s$. [...] having regard to the provision made for (1) suitable instruction in the elementary subjects, (2) simple lessons on objects and on the phenomena of nature and of common life, and (3) appropriate and varied occupations" (Committee of Council on Education 1895, 18). A far wider field of subjects were included in the inspections, which demonstrates an interest in a richer and more varied educational experience. In particular, the adoption of object lessons challenged the tedium of learning by rote, making schooling a more immersive and active experience. ${ }^{12}$ By 1895 , additional grants were available for the following subjects in day schools for older students: English, or Welsh (in Wales), or French (in the Channel Islands), Geography, Elementary Science, History, Object lessons, Suitable Occupations, Needlework and Domestic Economy (the latter two for female students only).

${ }^{11}$ Arnold's authorship was identified through his quarterly accounts. See "Mr Walter and Schoolmasters' Certificates" (1862, 257-61).

${ }^{12}$ Elizabeth Mayo's Lessons on Objects describes how the prevailing aim of object lessons was "to exercise the faculties of children according to their natural order of development, aiming also at their harmonious cultivation" $(1866,6)$. 
The purpose of the above narrative re-tracing of the rise and fall of Payments by Results within an educational context is designed to emphasise two important claims. First, that is entirely possible, and indeed historically demonstrated through the example of Lowe's Code, that a national system of economised education can be reversed through the very same policymaking process with which it was instituted. Second, historical records demonstrate how economism within education was a personal preference of certain nineteenth-century policymakers as opposed to being seen as the purpose of government itself. The wider context of costs, such as the Crimean War and the need for economic retrenchment, meant that Payment by Results was adopted at that particular moment in time. It is worth noting that these conditions were not shaped by an interest in education but rather in economics. The ensuing responses from Shuttleworth and Arnold demonstrate that an individual interrogation of the process of policy can lead to a clearer articulation of the results, particularly when they are placed within a richer explanatory context. Although the reversal of Lowe's Code was slow, the criticisms of the day played a productive role in its eventual abolition. These are all considerations that apply to the Browne Report as will be presently discussed in the second half of this chapter. How has the process of policymaking affected the result? Who are the beneficiaries of this economism? What might humanities scholars bring to an appraisal of Payment by Results in higher education? The following section pursues these questions, building upon the humanistic knowledge and understanding of policy reform in the 1860s established above.

\subsection{Part II: The Browne Report}

The focus of the enquiry now moves from the Victorian period to the present day. Shifting from the foundations of Payment by Results instigated in 1862, I shall presently define the conditions of higher education finance that were set into motion in 2009. The Browne Report, like Lowe's Code in its time, is an important milestone in the history of education in England. The report was a reiteration of the system of Payment by Results, but unlike the previous example, one that impacted the higher education sector. Moving between these two examples (Lowe's Code as foundational and most basic to the Browne Report as an advanced iteration) exposes circumstantial differences. For example, Victorian elementary education was increasingly supported by state finance and educational reforms throughout the mid-nineteenth century attempted to make attendance 
compulsory. ${ }^{13}$ Derek Gillard describes how "by 1851 the average length of school attendance had risen to two years, and in 1861 an estimated $2.5 \mathrm{~m}$ children out of $2.75 \mathrm{~m}$ received some form of schooling" (2011). By comparison, contemporary higher education is a non-compulsory consumer choice financed by invested stakeholders in the business of education. Therefore, Lowe's Code and the Browne Report should be understood to belong to their historical moment and as a product of their respective places within educational hierarchies. Nonetheless, as forms of Payment by Results, these two examples are among the most significant and vividly disputed moments in the ideological history of the system of English education. Considering them side by side can yield productive reflections.

In "The Cult of Efficiency in Education", Welch presents a convincing argument concerning the resemblance between Lowe's Code and the "recent and ongoing reform movements in the UK and Australia" (1998, 165). However, he does not investigate any specific act or policy document within his discussion of contemporary higher education. Welch's analysis of Lowe's Code reveals that the policy "coalesced around an agenda of cost containment, an increased business influence, $[\ldots]$ and an instrumental concern with enhanced system performance" (165). In relating the past iteration of Payment by Results with the present, Welch's study only goes as far as to identify how the white paper "Higher Education: Meeting the Challenge" explicitly promoted that higher education should take "increasing account of the economic requirements of the country" (Dept. of Education and Science 1987, 2). Welch correctly observes the echoes in the rhetoric from the educational debate in the 1860s within neoliberal management techniques since the 1980s. ${ }^{14}$ However, he does not consider the productive potential of analysis of corresponding critiques, nor does he seek to address the particular implications of these effects upon the contemporary higher education sector. I offer an analysis of policy that is comparative not only in a contextual sense but also in terms of its attentiveness to the processes of governance and the potential for humanistic critique.

\footnotetext{
${ }^{13}$ Most famously in the Elementary Education Act of 1870 (known as Forster's Act) but see also previous reform in the Factory Act (1833).

${ }^{14}$ An extended contemporary history of neoliberalism (1980-present) is provided in Chap. 5 with a discussion of New Public Management, accountability cultures, and impact assessment.
} 
As a result of this ambition, this section explores the formation and implementation of the Browne Report, demonstrating how it mirrors the structure and motivations of policymaking concerning Lowe's Code. The analysis begins with a summary of the purposes of the independent review and continues to explore the implementation of the review's findings, which were published on 12 October 2010 in a document called "Securing a Sustainable Future for Higher Education" (the Browne Report henceforth). With this context established, the discussion turns to criticisms and responses from those working within the university. This response principally consists of humanities scholars who critique the adoption of a free market for higher education. The connections and correspondences between Lowe's Code and the Browne Report are at times explicit, while elsewhere are less straightforward. The tensions in this attempt to draw these two policies into correspondence are developed in the conclusion of this chapter. As discussed in reference to Dinah Birch's Our Victorian Education in the introduction, the interconnection between Victorian policies and the present day can be illuminating even when they are not directly analogous.

\subsubsection{Contextualising the Browne Report: The Move Towards Minimal Government Involvement in Higher Education}

By the twenty-first century, England had experienced a publicly funded higher education system for nearly fifty years. The "Higher Education Report of the Committee appointed by the Prime Minister under the Chairmanship of Lord Robbins 1961-63" (known as the Robbins Report) actively argued that universities "should encourage the cultivation of high excellence" (Robbins 1963, 265), presenting an ambition for maximal rather than minimal standards of education. The Robbins Report suggested that there should be "an increase in public expenditure on full-time higher education from $£ 206$ million in $1962 / 3$ to $£ 742$ million in $1980 / 1$ " (Robbins 1963, 273). It explicitly advised against a system of private funding because this could "deter parents [...] from persuading, encouraging or allowing their children to proceed to Higher Education" (274). The late-twentieth century and, even more so, the early-twenty-first has seen great changes to the structures of higher education. Since the 1960s, 
student numbers have more than quadrupled, growing from around 400,000 full-time students in the 1960 s to over 2.3 million in $2017 .{ }^{15}$

During the 1990s there was a gradual increase in the amount of money paid by students in the form of student loans and tuition fees. A National Committee of Inquiry into Higher Education produced "Higher Education in the Learning Society" (known as the Dearing Report) in 1997. This white paper represented a significant milestone in public policy that moved away from blanket government funding for undergraduate education. The Dearing Report established a student contribution towards tuition fees of up to $£ 1000$ from 1998 and was instituted to relieve some of the burden of finances from public budgets to the private investor. The connection between the policy of the Dearing and Browne reports is well documented. For example, Gill Wyness' survey of "Policy Changes in UK Higher Education Funding 1963-2009" explains that "Dearing's main aim was to bring more money into the sector" $(2010,11)$. Although this article was published prior to the Browne Report, Wyness correctly anticipates how "given the current economic circumstances, perhaps the most important issue arising from the [Browne] review will be how to expand the HE system while cutting costs to the exchequer" $(2010,14)$. The Browne Report was framed as an economic manifesto for the future of higher education. The proposed policy offered a radical departure from the previous models of finance in its aim to reduce "the pressure on public spending" (Browne 2010,3). The Browne Report cites Dearing's work as fruitful while Robbins' more liberal and democratic vision is not mentioned. Within the Browne Report, Dearing's report is celebrated because it "focused on the role of higher education in contributing to international economic competitiveness" (Browne 2010, 18). This historical preference, favouring of Dearing over Robbins, is a clear indicator of the fiscal incentives behind the changes implemented through the Browne Report. Dearing's vision is cited as the initiation of the model to "create genuine competition for students between HEIs" $(2010,8)$ that the Browne Report intended to implement on a national scale. The following section explores the motivations for economic efficiency within the higher education sector.

\footnotetext{
${ }^{15}$ Total number of UK/EU Higher Education part-time and full-time students in England according to Higher Education Statistics Agency.
} 


\subsubsection{National Economic Motivations}

An immediate history of the Browne Report begins with Lord Peter Mandelson's first speech regarding higher education as Secretary of State for Business, Innovation and Skills, 27 July 2009. Speaking at Birkbeck, University of London, he stated that "higher education is not cheap", asserting that the country "had to face up to the challenge of paying for excellence" (2009). The language of this speech makes it explicit that Mandelson's primary interest in policymaking intervention in higher education was principally concerned with lowering its financial cost. The commissioning of the Independent Review of Higher Education Funding and Student Finance was the means by which to tackle this challenge. In November 2009, Lord Browne of Madingley was appointed to lead a review of fees and funding of higher education institutions. Browne's committee was asked to "examine the balance of contributions to universities by taxpayers, students, graduates and employers" (Hansard 2009, vol. $499 \mathrm{col}$. 4WS). The nature of this initial request to "examine the balance of the contributions" of education pre-empted any element of surprise at the financial focus of this report. Lord Browne, much like Lowe, is an economist best known for being the chief executive of multinational oil and gas company BP (1995-2007).

The circumstances in which a demand for economisation emerged are equally similar to the context of Lowe's Code. Although the Browne Report was commissioned under a Labour government in 2009, it reported to the Coalition government (2010-15), with Vince Cable replacing Mandelson as Secretary of State for Business, Innovation and Skills in May 2010. The context was, as with Lowe's Code, that of economic retrenchment. Stefan Collini observed in the London Review of Books, how the coalition was "using the whipped-up frenzy about the deficit in the public finances as a cover for a recognisably ideological assault on all forms of public provision" $(2010,25)$. Once more, the context of austerity was the setting for the adoption of Payment by Results as an effective and efficient means of value judgement in the education sector.

The Browne Report makes no efforts to conceal its process of costcutting. The report explains: "in our proposals, public spending reductions are made by removing the blanket subsidy [...] for all courses" (2010,27). The Browne Report is driven by an interest in the economics of education and finds no anxiety in speaking in solely fiscal terms. The statement that "higher education matters" is justified as follows: "higher 
education matters because it drives innovation and economic transformation" (14). University education and research is valued as a means to build a stronger economy. Some public investment remains, but only "to support priority courses and the wider benefits they create" (Browne 2010, $25)$. This change to the financial relationship between state and universities is significant. In this allocation of support, politicians behaved more like private investors than as part of a public support system, directing money where it saw the opportunity for direct profit or "wider benefits" (25). Such statements suggested that knowledge, and by extension higher education, was only deemed valuable when it has a direct use or is of immediate profit to the economy.

The changes to block grants in 2010 meant that the government no longer provided funding for any taught undergraduate courses in the humanities or social sciences. In allowing the market to dominate the financing of universities, the only assurance of any public money was for "priority courses" (Browne 2010,8). These courses are generally based around skills that are in high demand in the public sector, for example, "courses in science and technology subjects, clinical medicine, nursing and other healthcare degrees" (47). According to the Browne Report, these are "the courses [that] are a priority for the public interest" (47) whilst education in the humanities and arts courses is left in omission, signifying their positioning as a consumer choice. In an interview with The Telegraph, Cable explained that although politicians cannot directly control universities they "can create a framework in which universities that don't deliver will be subject to financial discipline. They will be operating in a market" (2010). The image of delivery emphasises the outcome-driven conception of value. Cable's comment also acknowledges that externally imposed governance structures and frameworks can profoundly alter the way in which universities operate. A reliance on market rationality is indicative of the government seeking to avoid defining higher education as a public good in itself.

In a context in which many public services are shifting towards becoming private corporations, it is not surprising that higher education is facing a similar future. ${ }^{16}$ However, few academics anticipated the extremes of this change in the complete removal of public funding of the block grants to the arts, humanities, and social sciences. This economisation is a symptom of the government's desire to make cuts to the budget rather than to

\footnotetext{
${ }^{16}$ Some prominent examples include British Telecoms (1984), national rail networks under the Railways Act (1993), and the Royal Mail (2014).
} 
improve the quality of higher education in the long term. The Browne Report explicitly states that the government benefits from being "less involved" $(2010,9)$ with the higher education sector by requiring "less regulation" (9). Therefore, it should be understood that the Browne Report was motivated by the desire to reduce public spending and deregulate the "marketplace of ideas", to borrow Louis Menand's expression. ${ }^{17}$ The report explains that "we are reducing the reliance of the system on funding from Government and control by Government" (Browne 2010, 46). Then-Chancellor of the Exchequer, George Osborne, was accused of influencing the review panel, which was supposed to be independent of departmental interests. A report by the Institute for Fiscal Studies (IFS) released on the same date as the Browne Report provided an independent analysis of the proposals. The IFS confirmed that "the public purse would be the main beneficiary of the proposed reforms", and explain how "the exchequer [...] would save up to $£ 6,000$ on the cost of a degree for each student" $(2010,1)$. Whether the review was truly independent of government or not, the results were clearly in favour of limited spending on higher education in the public budget book.

The immediate consequences of adopting this private model of student finance were twofold. First, the revelation that government subsidy would only be offered to subjects that produced tangible services in the national economy prompted widespread concern amongst scholars in the arts, humanities, and social sciences. The Browne Report made concrete what had previously been a growing suspicion: that higher education was being considered as a national commodity. Second, there was a noticeable reallocation of financial responsibility in terms of tuition being largely paid for by individual students. The rise in data concerning student satisfaction and league tables testifies to this change. The specific effects of this iteration of Payment by Results will be addressed in the following two sections. After a consideration of how government retrenchment in public spending reconfigures the value of higher education as a service industry for the provision of skills, I reflect on the potentially productive space of individual student values. The tension between neoliberal governance and the aspirations for a liberal education is key in exploring the implications of these changes.

\footnotetext{
${ }^{17}$ See title of Menand. L. The Marketplace of Ideas: Reform and Resistance in the American University (2010).
} 


\subsubsection{National Gains: The Debate Concerning Tangible Knowledge}

The Browne Report makes no effort to conceal the government's approach to cost-cutting: "in our proposals, public spending reductions are made by removing the blanket subsidy $[\ldots]$ for all courses" $(2010,27)$. Public investment remains only "to support priority courses and the wider benefits they create" (25). As a result, higher education funding from the government provides support for STEM subjects (Science, Technology, Engineering, and Mathematics), which are able to produce outcomes that Martha Nussbaum describes as "immediately useful discovery" (2010, 129). The Browne Report does not once specifically refer to the humanities or the social sciences, which does little to restore confidence in any governmental interest in liberal education.

It is unsurprising then that many humanities scholars do not feel that the Payments by Results system offers a suitable model of valuation for higher education. Colleen Lye et al. argue that such policy is indicative of universities being repositioned "as a business whose primary purpose is to drive economic growth, and whose activities are expected to be profitable" $(2011,2) .{ }^{18}$ The language that describes universities as sites for "economic growth" "profit" and "business" enterprises lies outside of the vocabulary traditionally associated with the humanities. Lye et al. describe the current changes to higher education as resulting from "a consumerist view of education that resignifies it as a private investment instead of a public good" $(2011,2)$. Collini wryly notes how the "responsibility for higher education has now been subsumed into Lord Mandelson's Department for Business" $(2009,19)$. Such conceptions of higher education indicate that the government is interested in the economically valuable and external benefits to industry that are made available through advanced training. The Browne Report documents a marked shift in government involvement in higher education. The focus on global competition and internal comparison mechanisms reveals a state that no longer takes responsibility for the funding of universities.

This approach has led to the vast expansion of data collection and statistics, which attempted to categorise, evaluate, and substantiate the value of specific universities. In "Operationalizing Hope: The Neoliberalization of British Universities in Historico-Philosophical Perspective", Gagnier

\footnotetext{
${ }^{18}$ For further example see Amsler S. (2011); Barnett R. (2011).
} 
observes that "traditional markers of academic distinction $[\ldots]$ have been overtaken by internally established criteria of worth [in] compliance or alignment with the University's competitive drive in a global Higher Education market" $(2013,11)$. Higher education is transformed into a commodity in an international marketplace, with universities becoming the providers of varying standards of education and setting their prices accordingly. Value cannot be attributed as absolute but instead as relational within the free market of education. As Samuel Bailey crucially established as early as 1825 in A Critical Dissertation on The Nature, Measure and Causes of Value, "value denotes consequently nothing positive or intrinsic, but merely the relation in which two objects stand to each other as exchangeable commodities" (4-5). Higher education has become a contemporary example of the age-old principle that quantitative values are not intrinsic but instead externally constructed through comparison, and in the particular case of student tuition through comparative league tables.

Writing in Times Higher Education, 7 October 2010, Claire Callender poses a vital question that many humanities scholars are continuing to attempt to answer:

according to Browne, the government should only fund 'courses that $[\ldots]$ provide skills and knowledge currently in shortage' such as science, technology, medicine, nursing, healthcare and 'strategically important' languages. What does this say about how society values the arts, humanities and social sciences? (2010)

The implicit valuation and support of "strategically important" (Browne $2010,47)$ courses implies an indirect disregard for that which it omits. The Browne Report institutes an $80 \%$ cut in government grants to teaching. ${ }^{19}$ Callender's question, "what does this say about how society values the arts, humanities and social sciences?" requires an answer since it reveals a lack of valuation for a large proportion of academic disciplines. STEM subjects are perceived to provide immediate discoveries and are able to produce economically beneficial knowledge. The government support of such quantified education is a manifestation of the system of Payment by Results in its extreme.

\footnotetext{
${ }^{19}$ See Paton, G. (2010) “Lord Browne Review: University Teaching Budgets Slashed by $80 \%$ ".
} 
I argue that in terms of government motivation, the present situation of higher education is much like that of the educational reforms of the 1860s. The removal of the HEFCE block grant for all undergraduate courses reflected policymaking "decisions about whether the courses are a priority for the public interest" (Browne 2010,47). The present system of Payment by Results since 2010, is akin to Lowe's Code in the sense that it seeks to reward those skills that are most sought after on a national scale. In elementary education in 1862 , basic literacy and numeracy were state priorities. In the context of contemporary higher education, the focus is on training a generation of specialists for certain jobs. ${ }^{20}$ The present method of government investment suggests that higher education is not financed as an end in itself, but a means of creating the necessary skilled workers to meet national labour demands. What is being paid for in governmental investment in higher education is a human product, be it a doctor, technician or engineer. Any alternative values of higher education are not valued in the policymaking practice of Payment by Results.

In the 1860s, Lowe's Code implemented the Payment by Results system as a catchall for basic literacy and numeracy skills. The Browne Report adopted the system for the opposite reason; its interest was in paying for the most specialised expertise that was in short supply and great demand both at the level of the national economy and the individual prospective student. The knowledge that the respective systems of Payment by Results funded were skills that at the time were deemed to be essential, useful, and beneficial to the nation. It is no coincidence that in a policymaking context, which demands measurable and short-term results, these kinds of knowledge were also quantitatively assessable. In contrast to the 2010 s, the minimal model of assessment under Lowe's Code was favourable due to the primitive nature of public intervention in education and the need for efficiency to reduce government spending. In 1862, a system of Payment by Results was adopted as a foundational attempt to lay the groundwork for a universal system of elementary education in a disordered system.

Cutting subsidies for non-essential subjects in the Browne Report is in many ways a re-invention of the Payment by Results policy of the 1860s. In both instances, the government chose to only pay for subjects that produce readily measurable results in national high demand. In both Lowe's

\footnotetext{
${ }^{20}$ For example, the training of medical professionals is subsidised by the government in order to relieve the strain on the NHS as England's population lives longer; 2011 Census data show that one in six people in England and Wales (over 9 million in total) are over 65.
} 
Code and the Browne Report, the primary impetus behind government action is the same: to regulate the amount of public money spent on education. In 1859, the Newcastle Commission was instructed: "to inquire into the state of public education in England and to consider and report what measures, if any, are required for the extension of sound and cheap elementary instruction to all classes of the people" (Newcastle 1 my italics). Similar aspirations for cheapness endure in the Browne Report: "the pressure on public spending has increased significantly" $(2010,3)$ and "public resources [are] now limited" (25). The model of Payment by Results has been repeatedly assumed to be the best strategy for education to deliver "value for its money" (Hansard "Mr Lowe" 1862a, vol. 165 c. 230 ) in England. It takes the work of a humanities scholar to point out that this is not an accidental or natural event, but the result of a particular policymaking practices. Through interrogating policy, as phenomena to be understood in and of themselves, this chapter has served as a reminder of "the ways in which developments in economic thought were contested in the past" (Gagnier 2000,5), in order to advance a critical consideration of the present.

Looking from this historical example to higher education today, one might expect to notice a difference in the governmental expectation of quality. This is not the case. An assurance of minimum levels of quality, the logic inherent in Payment by Results, has resurfaced in the Browne Report. The report explicitly states how in the free market of higher education "the interests of students will be protected by minimum levels of quality enforced through regulation" (Browne 2010, 3). "Minimum levels" (3), the devout interest of the economising administrators of 1862, pervades present educational policymaking through government regulation of education under the Payment by Results model. Shifting from Lowe's Code, to 150 years in the future, one might assume that the policymaking systems integral to education had evolved significantly. The excuses and allowances permitted to Lowe's Code, as a system in its primitive stages of development, cannot apply to this contemporary example. The reprise of minimal investment models and the Payment by Results system is the result of a different set of circumstances than those facing policymakers in the 1860s wherein a neoliberal faith in the market seeks to reduce the values of education to an economic scale.

The national incentive to encourage students to study subjects that are valuable to the economy has not only been criticised by scholars in the arts and humanities. Aaron Porter (then President of the National Union of 
Students 2010-11) argued that "the true agenda [of the Browne Report] is to strip away all public support for arts, humanities and social science provision in universities and to pass on the costs directly to students' bank accounts" (qtd. in Richardson 2012). Speaking in economic terms, Porter criticises the devaluation of the arts and humanities. Across higher education organisations, research networks, and in the popular press, the cuts integral to the Browne Report were perceived as a dismissal of the value of the humanities at the level of government. As a result, much of the criticism of the report has attacked the purely economic focus and the subsequent marketisation of education and sought to re-assert the importance of a humanistic education. This criticism is addressed in the final section of this chapter, but I will first address a significant point that Porter makes in identifying how the cost is passed onto students. The following section explores how the student is configured as being a customer of education, able "to 'pay more' in order to 'get more"" (Browne 2010, 4).

\subsubsection{The Rise of Individualism and the Student as Consumer}

Despite seeking to reduce the public spending at a national level, the Browne Report also places a great deal of emphasis on the individual benefits of higher education. As seen above, higher education "matters" because of the contribution it makes to "innovation and economic transformation" (Browne 2010, 14). However, the following paragraph offers an additional reason that higher education is important: "because it transforms the lives of individuals" (14). At a surface level, this appears to offer a more holistic approach to the valuation of education, a momentary acknowledgement of alternative values. This optimistic misconception is quickly proven false, as the report repositions the individual solely within the market. The subsequent sentence completes the picture: "on graduating, graduates are more likely to be employed, more likely to enjoy higher wages and better job satisfaction, and more likely to find it easier to move from one job to the next" (Browne 2010, 14). The individual student is immediately configured within an economic framework, as a worker seeking training in order to earn "higher wages" (14).

However, in placing financial liability "in the hands of the student" along with the freedom of making a consumer "choice" (3) the present iteration of Payment by Results is no longer solely connected with state finance, but extends its logic to the public as potential individual consumers of higher education. As a result, universities are required to compete 
for tuition fees in a competitive market, in order to maintain their humanities and social sciences courses. Failing to attract students equates to a failure to sustain courses that are no longer subsidised by the government. This particular instantiation of Payment by Results places the student (or the legal guardians of the student) in the position of assessor and as the ultimate attributor of value. Therefore, instead of limited criteria, the potential number of assessors with varying values and educational needs is vast. Students base their choices of a university (and, therefore, investment) on data concerning a long list of variable factors including course content, teaching quality, price, environment, league-table position, historic reputation, transport links, employment figures, and student satisfaction surveys. There are also unquantifiable reasons, both conscious and unconscious, for choosing a course or a university. Value for a student can be a more personal and complex choice than the government subsidy for useful (practical and prioritised) courses acknowledges.

Many students seek out concise sources of data, such as league tables, in order to make their individual choice. Studies indicate that institutional reputation continues to influence student choice to the greatest extent. ${ }^{21}$ In order to attract the highest calibre of applicants, a university must demonstrate world-leading research (most commonly exemplified by the ranking in the REF and grant incomes) and attain respectable league table positions (for categories such as student satisfaction or graduate job destinations). ${ }^{22}$ Sir Steve Smith (President of Universities UK 2009-11 and Vice Chancellor of the University of Exeter 2002-present) explicitly recognises that attracting the best students, in turn, leads to better statistics. ${ }^{23}$ Brighter students are assumed to do better at university and therefore numbers of A Level AAB+ grade students are proportional to league table positions. In an interview with the Sunday Times, 31 July 2011, Smith describes how "those students become like gold dust for their [university's] reputation. So you might have an incredibly strong series of incentives" (2011). This admission complicates the simple buyer-provider relationship that the Browne Report sought to establish in putting "students at the heart of the system" (25). In this system, students who obtain $\mathrm{AAB}+$ grades are equally commodified, being seen as products to be

\footnotetext{
${ }^{21}$ Connor, H. et al. (1999); Dunnett, A. et al. (2012) 12; Diamond, A. et al. (2012).

${ }^{22}$ For example, see the National Student Survey (NSS) or the Destinations of Leavers from Higher Education (DLHE) survey.

${ }^{23}$ 'Best' in the sense that they are deemed to be the most economically valuable to the institution. Obtaining AAA grades at A-Level.
} 
bargained for in exchange for the "value-added" to an institution in the form of future statistics.

There has been a proliferation of data surrounding higher education since 2010. Although higher education organisations have a wealth of statistical evidence regarding the impact of the changes that are occurring within the neoliberal university, there is an urgent need for humanities to interpret them. Franco Moretti argues that humanistic engagement with data can reveal new and significant phenomena through methodologies that close reading occludes. However, more important is the recognition of a need for humanities scholars to engage and critique data that accounts for value. In Graphs, Maps, Trees: Abstract Models for a Literary History, Moretti identifies that "the real point, here, is less the specific answer, than the total heterogeneity of problem and solution: to make sense of qualitative data, I had to abandon the quantitative universe, and turn to morphology: evoke form, in order to explain figures" $(2005,24)$. Although in policy data might be initially considered as "independent of interpretation" (33), Moretti argues they can be challenged, and indeed challenging, since once generated they rely on non-computational and qualitative skills of interpretation in order to have meaning or use. Under the changes of the Browne Report, and the implementation of the student as a consumer, any payment to universities becomes subject to its relational value within the dataset. Purely "intrinsic" value is not a calculable feature of the higher education market. The consequences of the changes to education are only beginning to be fully realised. The kinds of humanistic data analysis that Moretti performs upon the literary canon in Graphs, Maps, Trees should be adopted and applied to the proliferation of information concerning the contemporary university. The following discussion explores such interpretation of student application numbers.

Universities and Colleges Admissions Service (UCAS henceforth) applicant data reveals a decline in applicants when the $£ 9000$ tuition fees were implemented in 2012. The Guardian published an extensive analysis of this data online, 30 January 2012, reporting that "total applications to UK universities were down by $7.4 \%$ on last year" and "languages and art related subjects are feeling the biggest decreases; non-European languages are down $21.5 \%$ and creative arts and design are down by over $16 \%$ " (Datablog 2012).

This decrease in applications was only a temporary effect of the changes to higher education funding, and as Fig. 2.1 demonstrates, the drop in total applications was soon reversed; in 2017 there were more students 


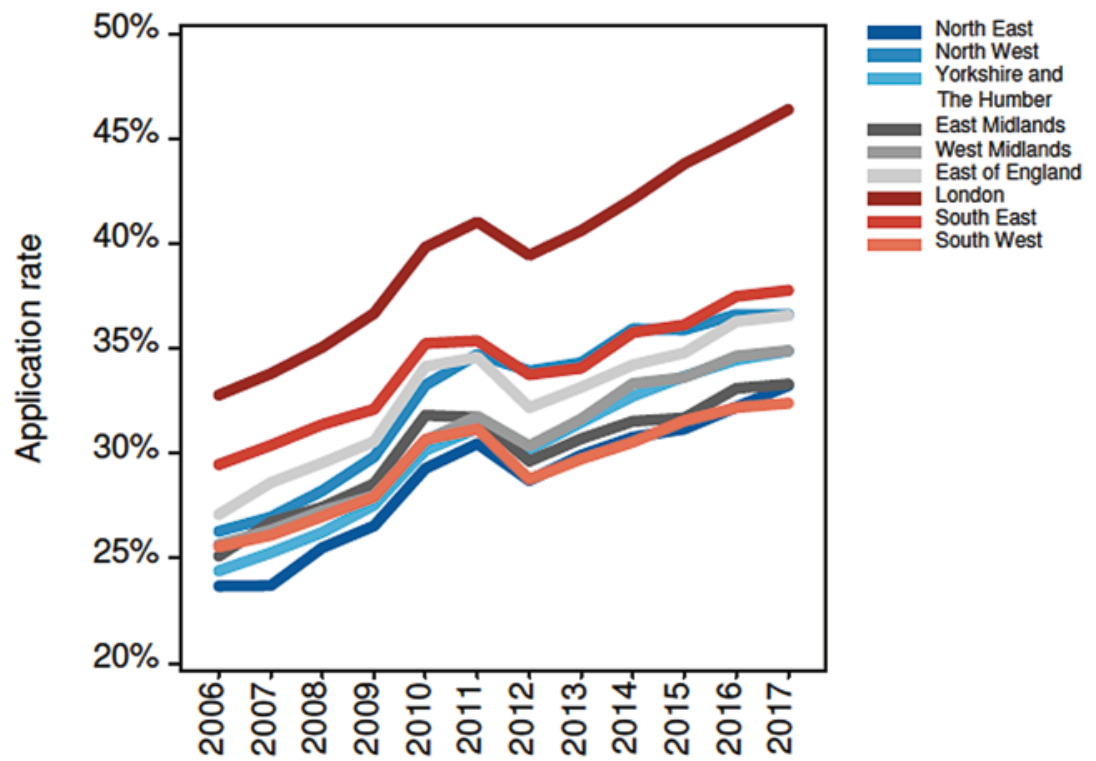

Fig. 2.1 University application rates for English 18-year-olds between 2006 and 2017. (Graph source: "UCAS Application Results by the January Deadline 2017 cycle." UCAS Analysis and Research, February 2017, 12)

currently in higher education institutions in England than at any other point in history.

Whilst the 2013 data revealed an increase in the number of students electing to study disciplines in the category of the creative arts (although not at the same level as 2011) there was a continued drop in the percentage of students electing to study the arts and humanities generally. As Fig. 2.2 demonstrates, 2013 saw a further decrease of $6.1 \%$ in "European Langs, Lit" since 2012, and a 6.7\% decrease in Non-European Langs, Lit" categories. ${ }^{24}$ This negative percentage score refers to a comparison between the present year and the number of applications the year before (in this

${ }^{24}$ The division of these subjects follows UCAS' Joint Academic Coding System (JACS 3.0) first implemented in 2012. In this, "European Langs, Lit" consists of French, German, Italian, Spanish, Portuguese, Scandinavian, Russian \& East European, European Studies and 'Others' in European languages, literature \& related subjects. "Non-European Langs, Lit" includes Chinese, Japanese, South Asian, 'Other' Asian studies, African, Modern Middle Eastern, American, Australasian studies and 'Others' in Eastern, Asiatic, African, American \& Australasian languages, literature \& related subjects. 
Percentage change in total applications by subject group 2012-2013

'Group I Computer Sciences'

'Group C Biological Sciences'

'Group D Veterinary Sciences, Agriculture and related'

'Group P Mass Communication and Documentation'

'Z General, other combined and unknown'

'Group H Engineering'

'Group F Physical Sciences'

'Group M Law'

'Group B Subjects allied to Medicine'

'Group G Mathematical Sciences'

'Group L Social Studies'

'Group N Business and Admin studies'

'Group V History and Philosophical studies'

'Group W Creative Arts and Design'

'Y Combined social sciences'

'Group A Medicine and Dentistry'

'Y Combined sciences'

'Group J Technologies'

'Group Q Linguistics, Classics and related'

'Y Social Sciences combined with Arts'

'Group K Architecture, Building and Planning'

'Group X Education'

'Y Combined arts'

'Group R European Languages, Literature and related'

Group T Non-European Languages, Literature and related'

'Y Sciences combined with Social Sciences or Arts'

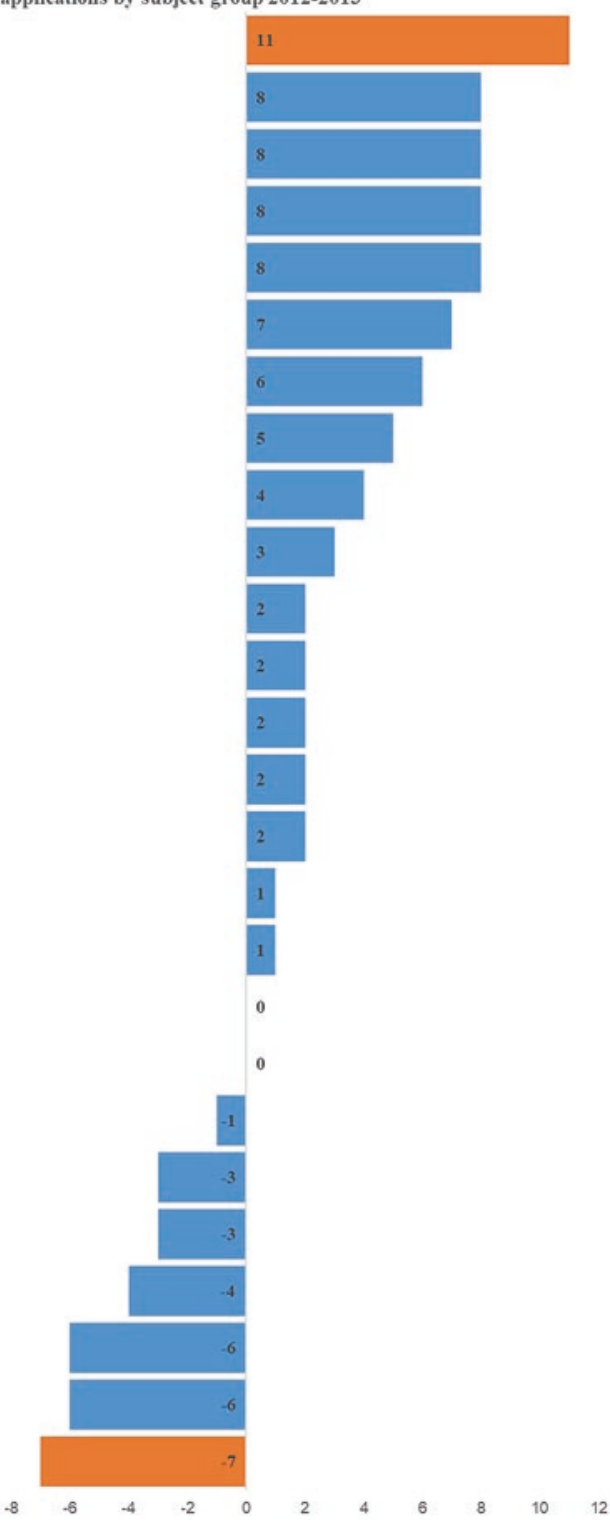

Fig. 2.2 Percentage change in total applications by subject group from 2012 to 2013. (Graph authors own, data source: "End of Cycle 2017 Data Resources." UCAS Analysis and Research, January 2018) 
Percentage change in total applications by subject group 2013-2014
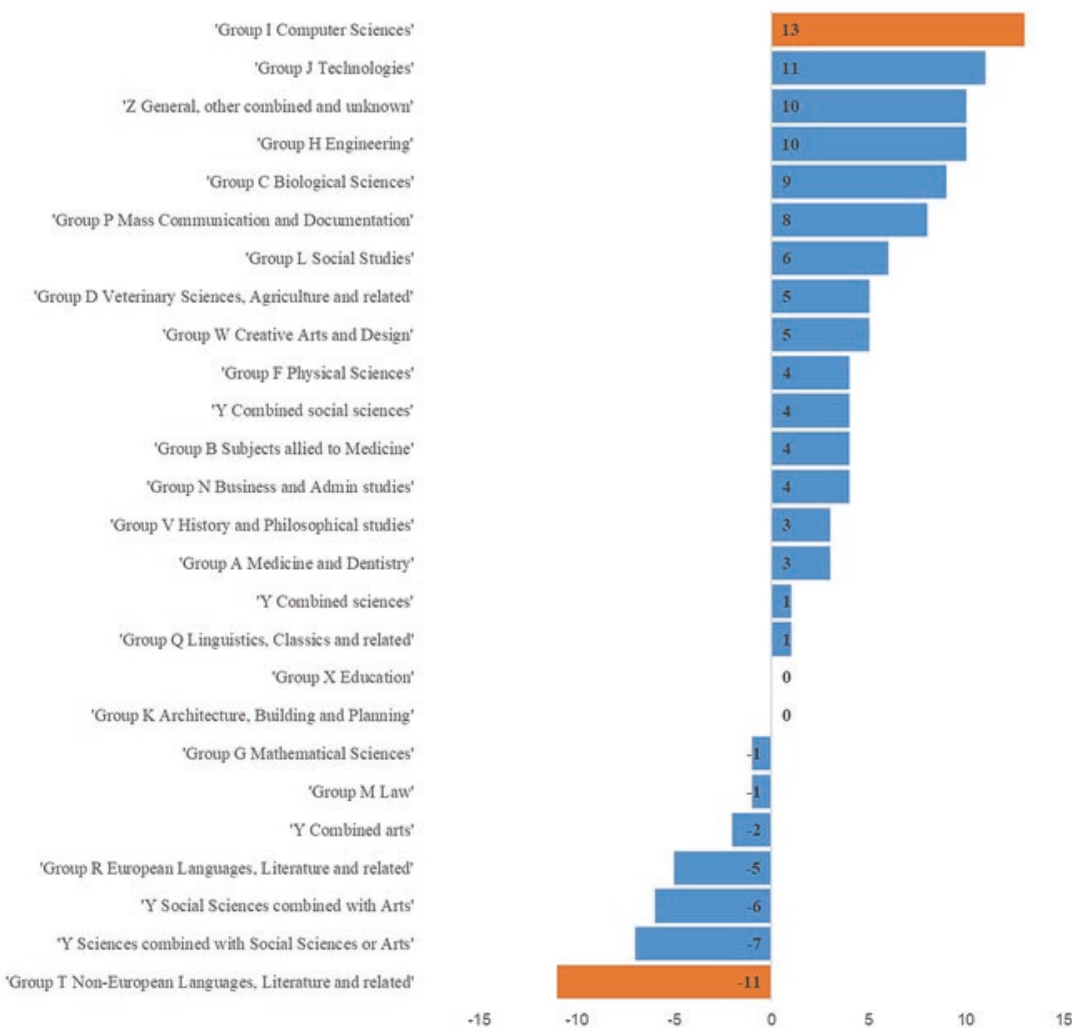

Fig. 2.3 Percentage change in total UCAS applications by subject group from 2013 to 2014. (Graph authors own, data source: "End of Cycle 2017 Data Resources." UCAS Analysis and Research, January 2018)

case, 2012), which were already lower than the previous year. "Hist \& Philosophical studies" was the only humanities category with increased student application numbers in 2013 at $+2.3 \% .{ }^{25}$ I have also constructed a graph based on the same type of UCAS data set (Applications by Subject Group) for 2014 (see Fig. 2.3).

${ }^{25}$ UCAS JACS 3.0 defines "His \& Philosophical studies as including broadly-based programmes within historical \& philosophical studies; History by period; History by area; History by topic; Archaeology; Philosophy; Theology \& religious studies; Heritage studies and 'Others' in historical \& philosophical studies". 
Figure 2.3 shows the percentage difference between the numbers of applications in the 2014 UCAS cycle in contrast to $2013 .{ }^{26}$ It paints a negative picture for the humanities between 2012 and 2014. Figure 2.3 demonstrates that language-based humanities have experienced the most significant drop in student applications. It is perhaps unsurprising to note that engineering and computer sciences saw an annual increase in student numbers since 2012. The Browne Report explicitly identifies engineering as being "important to the wellbeing of our society and to our economy" (Browne 2010, 25) and both subjects continued to "attract investment from the HE Council" (47) to support undergraduate tuition. However, not all statistics demonstrate a state of crisis for our disciplines. Although The Guardian headline, 31 January 2014, reads "Why the Drop in University Applications for Languages is Worrying" (Vincent 2014) and The Telegraph, 14 February 2015, reports a "Dramatic Decline in Number of University Students Taking Modern Foreign Languages" (Turner 2015), the state of the disciplines were less clear-cut when assessed on a wider scale. I generated the following graph (see Fig. 2.4) from the actual number of applications as opposed to the percentage increase or decrease year-on-year. The graph generated from the UCAS raw data is quite different. Perhaps, as Moretti argues, "quantification poses the problem, then, form offers the solution" $(2005,33)$. In considering the data across the span of four years, student interest in the humanities is not as negative. Although in 2012, the first year after the tuition fees and grant removal was implemented, there is a noticeable reduction in applicants in the humanities, Fig. 2.4 reveals no further significant decline in subsequent years in "Linguistics, Classics and Related" or "Hist. \& Philosophical Studies". ${ }^{27}$

Such data reflects that the attitude of "depressive disorientation" (Amsler 2011, 64) in the humanities may yet be surpassed, as a momentary tremor in this period of rapid transformation within higher education. The purpose of constructing these graphs is to demonstrate that although the Browne Report instituted a radical departure in the financing structure

\footnotetext{
${ }^{26}$ The data is published annually in January following the end of the main UCAS application cycle. Data cited in this chapter refers to applicants in England specifically, although data for all domiciles in the UK is available.

${ }^{27}$ UCAS definitions of "Linguistics, Classics and Related includes: Broadly-based programmes within languages; Linguistics; Comparative literary studies; English studies; Ancient language studies; Celtic studies; Latin studies; Classical Greek studies; Classical studies; Others in linguistics, classics \& related subjects".
} 


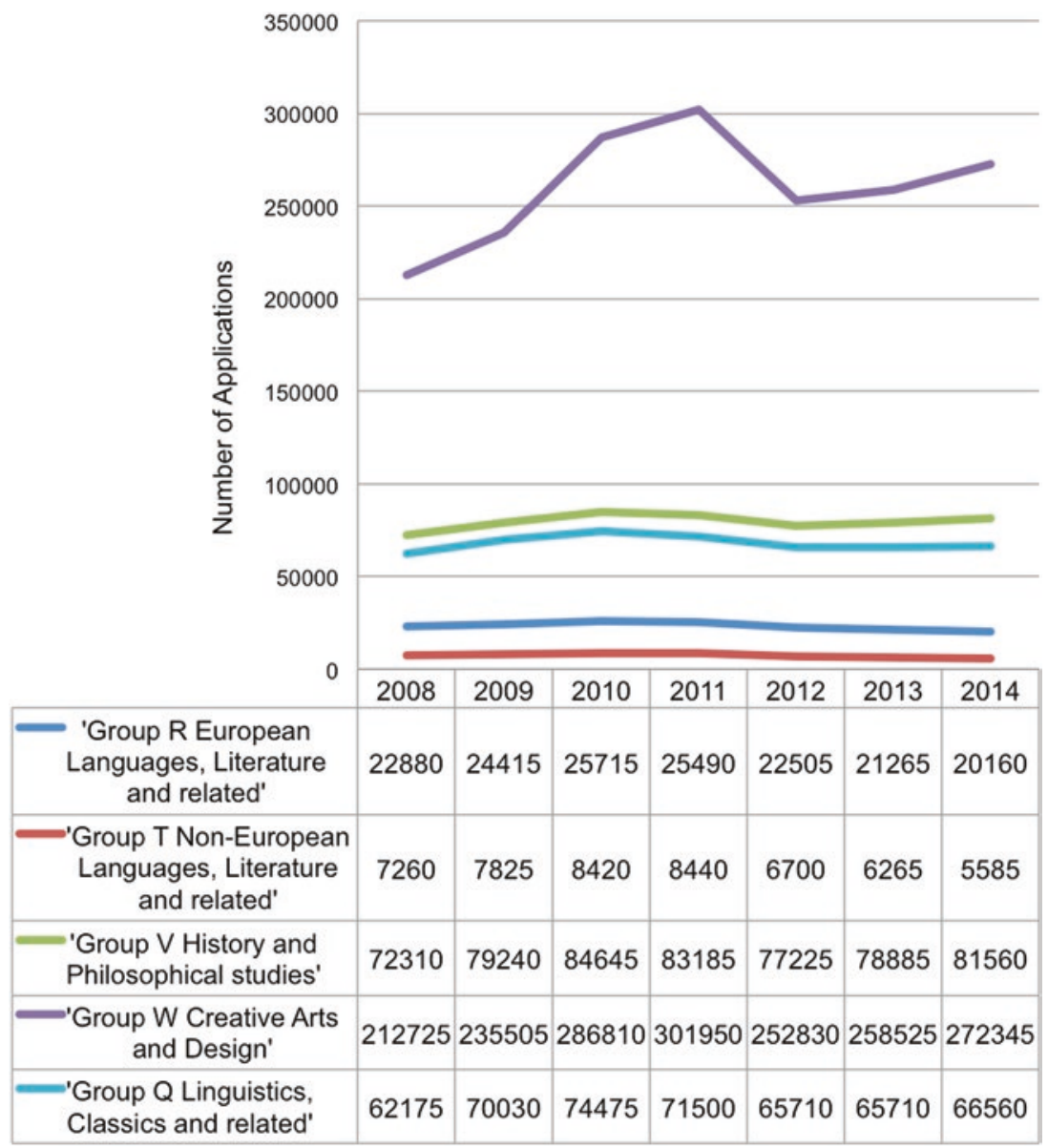

Fig. 2.4 UCAS Humanities Subject Applications 2008-14, Number of Applicants. (Graph authors own, data source: "January Deadline Analysis: Subjects." UCAS Analysis and Research, 30 January 2015)

of higher education, the results are yet to be fully understood. Small argues an attentiveness to "the extent to which the value of a higher education, not only in the humanities, continues to be understood by students, teachers, parents, alumni $[\ldots]$ in ways that resist market valuation and economic 
quantification" $(2013,21)$. As humanities scholars, we should challenge the assumption that the transformation of the student into a consumer by policy is accompanied by a student's willingness to be framed as one.

The Browne Report makes clear that a university education is an individual's investment and not a public good. The report places "students at the heart of the system" $(2010,27)$ through personal and private investment, which changes higher education irrevocably: a complex consumer market of specialised wants replaces the assessment of minimum requirement of needs. Collini observes that the Browne report "in keeping with the ethos of market populism, shies away from anything that might look to involve a judgement that one activity is more worthwhile than another: all you can go by are consumer preferences, what people say they think they want" $(2010,24)$. Reducing the financing of education to consumer preference is problematic. Collini offers an analogy which, although is somewhat infantilising, illustrates the chief trouble with such an approach. He writes: "children may be best placed to judge what they want to get from the sweetshop, but they are not best placed to judge what they should get from their schooling" (23). To assume that students are in the best place to decide what sort of higher education they "should get" (23) is not in keeping with policymaking in other areas of education. Nor, more importantly, why a country should be interested in educating its population.

The private student-led sector is very different from the allocation of government grants. Unlike the government administrator, the studentconsumer does not seek a sufficient level for all education but instead aspires towards marketable excellence or personal preferences. Like any consumer marketplace, entry into higher education has become increasingly competitive and prospective students are not happy to invest their money in what might appear to be a second-rate product. With "the student at the heart of the system" (Browne 2010, 25) education is no longer assessed solely by a minimum standard. An education is not necessarily desirable to a student for the same reasons that it might be useful to a government administrator. The incompatibility of these models of value forces wider changes: desire dominates a consumer market, whereas economic use dictates policymaking. Higher education is increasingly funded by the student who has a more complex and often individuated set of criteria for assessing the value of higher education than the simple version of minimum expectations inherent in Lowe's Code. 
Yet, in a talk presented at Birkbeck College, London just a month after the publication of the Browne Report, Iain Pears noted that "in a completely free market, the humanities would clean up". He argues that "faced with a choice between an arts degree costing $£ 8,000$ a year, and one in science costing upwards of $£ 30,000$ a year, history and philosophy would suddenly become very popular for all except those determined to become scientists" (2010). The blanket cost of courses in the UK conceals the internal financing of courses. John Crace similarly observes that universities are "about $£ 1,000-£ 1,500$ better off on every arts and social studies student" (2013) since the cost of teaching subjects such as English is cheaper than scientific subjects. The direct student tuition fees of $£ 9000$ are actually a higher source of income than previous government block grants for these disciplines. Student tuition from the humanities, however, does not get spent in the humanities department; cross-subsidy occurs within institutions whereby popular humanities courses subsidise expensive STEM courses. This area of higher education management is poorly communicated to the public and is generally opaque to prospective students. Christopher Newfield argues that "opening the books on crosssubsidies would allow the public to understand exactly why universities cost as much as they do. It would allow universities to honor the financial as well as the intellectual contributions of their cultural and social disciplines" $(2010,42)$. Although speaking in an American context, Newfield's observations are equally applicable to the practices of funding courses in England.

Although Lowe sought to introduce an exclusively economic model of valuation into education in the 1860 s, it was a temporary affair. His liberal economism would be tempered by the values inherent in a liberal education instituted in the Cross Commission, and a critical recognition that the highest quality of education could not be built on narrowness and cheapness. To conclude this chapter on a note of optimism, perhaps in the free market of education, which emphasises the individual benefits of higher education, the potential of Arnold's "general intellectual cultivation" $(1862,224)$ can yet be realised anew. The dangers of selfish liberalism, driven by competition, are as present now as they were in the nineteenth century. However, reading the intervention that Arnold made in his context, through "The Twice-Revised Code" stands as a reminder of the requirement for someone to assert the value of liberal education and offer a practical yet humanistic critique of policymaking approaches. The protests of Arnold and Shuttleworth remain the most unfettered and least 
defensive critiques of economisation in education to the present day. It is time that the humanities revive a stronger sense of assurance in the values that they seek to uphold. Openness, tolerance, critical thinking, communication, and cultural awareness might be hard to plot on a graph or capture in a survey of Gross National Product, but they are values that, if shared and developed, can challenge educational norms under neoliberalism.

\subsection{Conclusion}

This chapter began by returning to the roots of economic thinking in educational policymaking. The initial section traced the linguistic and legislative transformation of the Newcastle Commission into Lowe's Code. The actions of Parliamentary reform during the 1860s might be understood as a logical course of action aiming to provide a democratic framework for sustainable elementary education in England. However, closer critical analysis reveals that a short-term desire for a cheap system of governance was prioritised over the development of a suitable valuation model for schooling. I argue that the model of Payment by Results is a mechanism with which to institute a system of minimal assurances rather than maximal value. In tracing the history of Payment by Results, and providing a solid survey of the methods of government, this chapter contributes to a clearer understanding of how and why educational policy was economised between 1858 and 1888. Doing so provides a rich historical narrative with which to address the present changes in higher education under the Browne Report.

The second part of this chapter built upon these nineteenth-century debates to explore how the system of Payment by Results is manifested under neoliberal conditions. To date, interpretation of policy documents is an underdeveloped part of humanities research into the value of the humanities. It is easier to avoid engaging with policy, lamenting its effects as opposed to engaging in a progressive critique. However, the work in this chapter provides a methodological approach to engaging with white papers and Parliamentary speeches that relies on humanistic skills of close reading and critique within a historically nuanced framework. Such a critical approach was commonplace in the nineteenth century, as Arnold's "Twice-Revised Code" exemplifies. The second part of this chapter demonstrated how a policy preference for economic valuation shaped the development of the Browne Report and how neoliberal notions of privatisation, deregulation, and competition are the dominant politics of the 
higher education sector. I outlined how within this context a new relationship between the state, the university, and the student is established. Universities are no longer beholden to the government but to a market of consumer choice. Interpretation of application data demonstrates that, although the humanities have suffered as an immediate consequence of the increase in tuition fees, the emerging situation may still hold promise. The critical interrogation into the cost of courses, cross-subsidies, and the desires of student-consumers is not a common focus for humanities scholarship but, I argue, is a necessary one. This chapter highlights the question of whether a proliferation of student choice in a free market might benefit the humanities, with an increased sense of individualism being seized to renew an interest in a liberal education that benefits both individuals and their wider society.

In a competitive market, universities attract students by offering maximum opportunities, wide-ranging choice and quality degree programmes. The humanities should be able to articulate the value of their disciplines in terms that can appeal to student desires. The liberal arts, which increasingly encompasses the arts, humanities, and social sciences, offers students an educational experience which is predicated on openness and human understanding. National league tables might be omnipresent, but most do not offer the ability to rank specific disciplines above one another, instead, only comparing like with like. ${ }^{28}$

Reading the Browne Report can leave a humanities scholar feeling anxious due to its whole-hearted disregard for the qualitative traits and noneconomic values intrinsic to their disciplines. The complete lack of mention of the arts, humanities or social sciences by name throughout the Browne Report is deeply disconcerting. In practice, the government has chosen to support STEM subjects, leaving the teaching of the humanities, arts, and social sciences unsupported by public subsidies at an undergraduate level. Despite the cuts to the undergraduate teaching grants, public funding remains for research in humanities disciplines. ${ }^{29}$ The financial structures of universities change the relationships of disciplines within them, which have a range of positive and negative effects. For example within research,

\footnotetext{
${ }^{28}$ For subject-league table see The Guardian's annual subject league tables. The exception to cross-departmental data is the National Student Satisfaction Survey (NSS), however, this data is not (yet) used to compare departments in university marketing.

${ }^{29}$ The Research Councils UK continues to provide grants through the Arts and Humanities Research Council.
} 
humanities scholars have formed collaborations with colleagues in the social sciences and sciences that may not have come to pass if public grants for research were not so science-oriented. ${ }^{30}$ This chapter has demonstrated that the reformed higher education sector yields new possibilities alongside new challenges. Universities are no longer exclusively beholden to government interests and instead must rely on a firmer connection to students, non-academic institutions, the media, and the wider public. These alternative sites of value are explored throughout this book. Chapter 3 explores the relationship between STEM and the humanities, in which I analyse the debates between scholars across disciplines concerning value using their own terms, rather than being defined by the limited language of policy. Chapter 4 studies the connection between real-life and mediated representations in literary fiction, and Chap. 5 develops a prolonged interaction between higher education and museums.

\section{BIBLIOGRAPHY}

Advocate of Peace. 1869. Crimean War. Section II. Loss of Money. Advocate of Peace (1847-1884) l (8): 117-121.

Amsler, Sarah. 2011. Beyond All Reason: Spaces for Hope in the Struggle for England's Universities. Representations 116 (1): 62-89.

Arnold, Matthew. 1862. The Twice-Revised Code. Reproduced in The Complete Prose Works of Matthew Arnold: Democratic Education Vol. II, 1962, ed. R.H. Super, 212-243. Ann Arbor: University of Michigan Press.

- 1863. Mr Walter and Schoolmasters' Certificates. Reproduced in The Complete Prose Works of Matthew Arnold: Democratic Education Vol. II, 1962, ed. R.H. Super, 257-261. Ann Arbor: University of Michigan Press.

. 1864. The Function of Criticism at the Present Time. Reproduced in Culture and Anarchy, and Other Writings, 2001, ed. Stefan Collini, 26-51. Cambridge: Cambridge University Press.

- 1889. Reports on Elementary Schools 1852-1882. London: Macmillan and Co.

- 1895. Letters of Matthew Arnold 1848-1888. Collected and arranged by George W.E. Russell. London: Macmillan.

Bailey, Samuel. 1825. A Critical Dissertation on the Nature, Measure and Causes of Value. London: R. Hunter.

Barnard, Howard C. 1958. A Short History of English Education 1760-1944. London: University of London Press.

\footnotetext{
${ }^{30}$ Medical humanities, digital humanities, and neurolinguistics are valuable cross-disciplinary fields of research that are developing as a result of a changing grant system.
} 
Barnett, Ronald. 2011. The Marketised University: Defending the Indefensible. In The Marketisation of Higher Education and the Student as Consumer, ed. Mike Molesworth, Richard Scullion, and Elizabeth Nixon, 39-51. Abingdon: Routledge.

Birch, Dinah. 2008. Our Victorian Education. London: Wiley-Blackwell Manifestos.

Browne, John (Lord Browne of Madingley). [The Browne Report] 2010. Securing a Sustainable Future for Higher Education: An Independent Review of Higher Education Funding and Student Finance. October 12. London: BIS. Available at: www.gov.uk/Government/publications/the-brownereport-highereducation-funding-and-student-finance

Cable, Vince. 2010. Universities Will Get Less, and Graduates Will Pay More. Interview by Mary Riddell. The Telegraph, September 18. Accessed 12 Aug 2012, via www.telegraph.co.uk/news/politics/liberaldemocrats/8010479/ Vince-Cable-interview-Universities-will-get-less-and-graduates-will-paymore.html

Callender, Claire. 2010. The Browne Review: How Britain Reacted. Times Higher Education Online, October 7. Accessed 3 Aug 2013, via www.timeshighereducation.co.uk/413870.article

Collini, Stefan. 2009. Impact on Humanities: Researchers Must Take a Stand Now or Be Judged and Rewarded as Salesmen. Times Literary Supplement, November $13,18-19$.

- 2010. Browne's Gamble. London Review of Books 32 (21): 23-25.

Committee of Council on Education. 1895. Code of Regulations for Day Schools with Schedules and Appendices, by the Right Honourable the Lords of the Committee of the Privy Council on Education. C. 7652, London: HMSO. Accessed 10 Jan 2017, via parlipapers.proquest.com/parlipapers/ docview/t70.d75.1895-072896? accountid=10792

Connell, William Fraser. 1950. The Educational Thought and Influence of Matthew Arnold. Introduction by Fred Clarke. London: Routledge \& Kegan Paul Limited.

Connor, H., R. Burton, R. Pearson, E. Pollard, and J. Regan. 1999. Making the Right Choice: How Students Choose Universities and Colleges. Brighton: Institute for Employment Studies. Accessed via: www.employment-studies.co.uk/ resource/making-right-choice-how-students-choose-universities-and-colleges

Crace, John. 2013. Steve Smith: 'Life Is Sweet - But Tough'. The Guardian, July 29. Accessed 7 Dec 2017, via www.theguardian.com/higher-education-network/blog/2013/jul/29/steve-smith-interview-exeter-unviersity. [sic]

Cross Commission. 1888. Elementary Education Acts: Final Report of the Commissioners Appointed to Inquire Into the Elementary Education Acts, England and Wales. London: Eyre and Spottiswoode.

Datablog. 2012. University Applications: Where Did People Apply and for Which Subjects? The Guardian, January 30. Accessed 2 Apr 2017, via www.theguard- 
ian.com/news/datablog/2012/jan/30/university-applications-subjectsage-poverty\#data

Dearing, Ronald. 1997. [The Dearing Report] Higher Education in the Learning Society. National Committee of Inquiry into Higher Education. London: HMSO.

Department of Education and Science. 1987. Higher Education: Meeting the Challenge. Cm 114, London: HMSO.

Diamond, Abigail, Tim Vorley, Jennifer Roberts, and Stephen Jones. 2012. Behavioural Approaches to Understanding Student Choice. Leicester: CFE Research.

Dunnett, Andrew, Jan Moorhouse, Caroline Walsh, and Cornelius Barry. 2012. Choosing a University: A Conjoint Analysis of the Impact of Higher Fees on Students Applying for University in 2012. Tertiary Education and Management 18 (3): 199-220.

Fletcher, Laaden. 1974. Payment for Means or Payment for Results: Administrative Dilemma of the 1860's. Journal of Educational Administration and History 4 (2): 84 .

-1981. A Further Comment on Recent Interpretations of the Revised Code, 1862. History of Education 10 (1): 21.

Gagnier, Regenia. 2000. The Insatiability of Human Wants: Economics and Aesthetics in Market Society. Chicago: University of Chicago Press.

-2013. Operationalizing Hope: The Neoliberalization of British Universities in Historico-Philosophical Perspective. Occasion: Interdisciplinary Studies in the Humanities 6: 1-16.

Gillard, Derek. 2011. Education in England: A Brief History. Accessed 12 May 2015, via www.educationengland.org.uk/history

Hansard. 1861. Mr Lowe. Supply - Civil Service Estimates. HC Deb, vol. 164 cols. 719-69, July 11. Accessed via hansard.millbanksystems.com/commons/1861/jul/11/supply-civil-service-estimates

- 1862a. Mr Lowe. Education - The Revised Code O Regulations. HC Deb, vol. 165 cols. 191-257, February 13. Accessed via hansard.millbanksystems.com/commons/1862/feb/13/education-the-revised-code-oregulations

. 1862b. Earl Granville. Minute of Privy Council Presented. HL Deb, vol. 165 cols. 170-88, February 13. Accessed via hansard.millbanksystems.com/ lords/1862/feb/13/minute-of-privy-council-presented

- 2009. The Minister for Higher Education and Intellectual Property, Mr. David Lammy. Higher Education Funding and Student Finance (Review). HC Deb, vol. 499 col. 4WS, November 9. Written Ministerial Statements. Accessed via publications.parliament.uk/pa/cm200809/cmhansrd/cm091109/ wmstext/91109m0001.htm\#0911094000014

Institute for Fiscal Studies. 2010. Graduates and Universities Share Burden of Browne Recommendations. Press release. London: Institute for Fiscal Studies. 
Jabbar, Huriya. 2013. The Case of 'Payment-By-Results': Re-examining the Effects of an Incentive Programme in Nineteenth Century English Schools. Journal of Educational Administration and History 45 (3): 220-243.

Jenkins, Roy. 2012. Gladstone. London: Pan Macmillan.

Lowe, Robert. 1868a. Letter to Sir John Simon, 31 October 1868. In Robert Lowe on Education, edited by D. W Sylvester, 1974, 23. Cambridge: Cambridge University Press.

- 1868b. Middle Class Education: Endowment or Free Trade? London: Bush.

- 1868c. Middle Class and Primary Education. In Two Speeches by the Rt. Hon. Robert Lowe, MP, Liverpool. London: Robert John Bush.

- 1893. Letter to Ralph Lingen 17 March 1882. In Life and Letters of Viscount Sherbourne, ed. Patchett Martin, vol. II. London: Longmans.

Lye, Colleen, Christopher Newfield, and James Vernon. 2011. Humanists and the Public University. Representations 116 (1): 1-19.

Mandelson, Peter. 2009. Higher Education and Modern Life. Ministerial Speech. Birkbeck, University of London to Senior Representatives from Higher Education, Business and Media, 27 July.

Marcham, A.J. 1979. Recent Interpretations of the Revised Code of Education, 1862. History of Education 8 (2): 121-133.

Mayo, Elizabeth. 1866. Lessons on Objects, Graduated Series: Designed for Children Between the Ages of Six and Fourteen Years: Containing also Information on Common Objects. New York: Charles Scribner.

Menand, Louis. 2010. The Marketplace of Ideas: Reform and Resistance in the American University. New York: W.W. Norton.

Moretti, Franco. 2005. Graphs, Maps, Trees: Abstract Models for a Literary History. London: Verso.

Morris, Norman. 1970. State Paternalism and Laissez-faire in the 1860s. In Studies in the Government and Control of Education since 1860, History of Education Society. London: Methuen.

Newcastle, Duke of. [The Newcastle Commission]. 1861. Report of the Royal Commissioners Appointed to Inquire into State of Popular Education in England. Vol. 1. London: HMSO.

Newfield, Christopher. 2010. Avoiding the Coming Higher Ed Wars. Academe (American Association of University Professors) 96 (3): 38.

Nussbaum, Martha C. 2010. Not for Profit: Why Democracy Needs the Humanities. London: Princeton University Press.

Paton, Graeme. 2010. Lord Browne Review: University Teaching Budgets Slashed by $80 \%$. The Telegraph, October 12. Accessed 2 Nov 2016, via www.telegraph. co.uk/education/educationnews/8059307/Lord-Browne-review-universityteaching-budgets-slashed-by-80.html

Pears, Iain. 2010. Taxes, Banks, Loans, and Students. Paper Presentation. Why Humanities? Conference, November 4-5, Birkbeck College, London. Accessible via defendartsandhums.blogspot.co.uk/2010/11/why-humanitiestalks-from-birkbeck.html 
Rapple, Brendan A. 1990. Payment by Educational Results: An Idea Whose Time Has Gone? Thirty-Five Years of Experimentation with Educational Efficiency in England (1862-1897). Accessed 31 July 2013, via http://education.illinoisstate.edu/downloads/csep/series14.pdf

Richardson, Hannah. 2012. Spending Review: Universities 'to face $£ 4$.2 bn cut'. $B B C$ News: Education and Family, October 15. Accessed 23 May 2013, via www.bbc.co.uk/news/education-11550619

Robbins, Lionel Charles. 1963. Report of the Committee Appointed by the Prime Minister Under the Chairmanship of Lord Robbins. 1961-63. [The Robbins Report] Parliamentary Papers Cm 2154, London: HMSO.

Shuttleworth, James Kay. 1861. Letter to Earl Granville, K. G., on the Revised Code of Regulations Contained in the Minute of the Committee of Council on Education. November 4. Hathi Trust Digital Library. Accessed 6 Dec 2013, via http://hdl.handle.net/2027/mdp.39015062739654

- 1868. Memorandum on Education. London: W. Clowes and Sons.

Small, Helen. 2013. The Value of the Humanities. Oxford: Oxford University Press. Smith, Steve (Sir). 2011. Universities Cut Fees for Top Students. Sunday Times, July 31. Accessed 30 Apr 2017, via www.thetimes.co.uk/article/ universities-cut-fees-for-top-students-hqnlsfz78bt

Sylvester, D.W., ed. 1974. Robert Lowe on Education. Cambridge: Cambridge University Press.

Thorne, R.G., ed. 1986. Curtis, William (1752-1829), of Culland's Grove, Southgate, Mdx. The History of Parliament: The House of Commons 1790-1820. London: Boydell and Brewer. Accessed 10 July 2016, via www.historyofparliamentonline.org/volume/1790-1820/member/curtis-william-1752-1829

Timbs, John. 1825. The Mirror of Literature, Amusement, and Instruction. Vol. 5. London: J. Limbird.

Turner, Camilla. 2015. Dramatic Decline in Number of University Students Taking Modern Foreign Languages. The Telegraph, February 14. Accessed 7 Mar 2017, via www.telegraph.co.uk/education/universityeducation/11412441/ Dramatic-decline-in-number-of-university-students-taking-modern-foreignlanguages.html

UCAS Analysis and Research. 2014. UK Application Rates by Country, Region, Sex, Age and Background: (2014 Cycle, January Deadline). UCAS Analysis and Research, January 31. Accessed 3 Mar 2017, via www.ucas.com/file/1106/ download?token=lsFnkISo

- 2015a. Deadline Applicant Statistics. UCAS Website, March. Accessed via www.ucas.com/file/14146/download?token=pj-Z6OXN

- 2015b. January Deadline Analysis: Subjects. UCAS Analysis and Research, January 30. Accessed 3 Mar 2017, via www.ucas.com/file/10756/ download?token=TawMIJ_U

2017. UK Application Rates by the January Deadline: 2017 Cycle. UCAS Analysis and Research, February 2. Accessed 3 Mar 2017, via www.ucas.com/ file $/ 92746 /$ download? token $=4 \mathrm{Ij}-\mathrm{BMlr}$ 
2018. End of Cycle 2017 Data Resources. UCAS Analysis and Research, January 25. Accessed via https://www.ucas.com/file/144276/download? token $=\mathrm{AcKbT} 2 \mathrm{~g}$

Vincent, Nigel. 2014. Why the Drop in University Applications for Languages Is Worrying. The Guardian, January 31. Accessed 3 Mar 2017, via www.theguardian.com/education/2014/jan/31/drop-in-university-languageapplications

Wardle, David. 1976. English Popular Education 1780-1975. Cambridge: Cambridge University Press.

Welch, Anthony R. 1998. The Cult of Efficiency in Education: Comparative Reflections on the Reality and the Rhetoric. Comparative Education 34 (2): 157-175.

West, Edwin George. 1964. 'Public Versus Private Education': A Classical Economic Dispute. Journal of Political Economy 72 (5): 465-475.

Wyness, Gill. 2010. Policy Changes in UK Higher Education Funding, 1963-2009. Institute of Education, University of London. Accessed 20 July 2013, via http://repec.ioe.ac.uk/REPEc/pdf/qsswp1015.pdf

Open Access This chapter is licensed under the terms of the Creative Commons Attribution 4.0 International License (http://creativecommons.org/licenses/ by $/ 4.0 /$ ), which permits use, sharing, adaptation, distribution and reproduction in any medium or format, as long as you give appropriate credit to the original author(s) and the source, provide a link to the Creative Commons licence and indicate if changes were made.

The images or other third party material in this chapter are included in the chapter's Creative Commons licence, unless indicated otherwise in a credit line to the material. If material is not included in the chapter's Creative Commons licence and your intended use is not permitted by statutory regulation or exceeds the permitted use, you will need to obtain permission directly from the copyright holder.

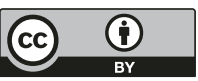

